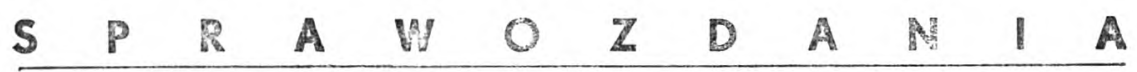

\author{
Ks. Antoni Pietrzyk MSF
}

\title{
SEMINARIUM NAUKOWE POŚWIECONE MUZYCE W KATEDRACH POLSKICH
}

W dniach 24-25 września br. ođbyło się w gmachu Wyższego Seminarium Duchownego w Łomży naukowe seminarium poświęcone muzyce w katedrach polskich. Seminarium to połaczone zostało ze statutowym zjazdem członków Sekcji Wykładowców Muzyki Kościelnej w Polsce. W seminarium wzięło udział 30 członków Sekcji. W trakcie trwania seminarium wygłoszone zostały następujące referaty:

1. Zarys dziejów muzyki w kateđrze wawelskiej (Marta Pielech - Warszawa UW).

2. Dzieje muzyki w katedrze chelmińskiej w Chełmży i Pelplinie (ks. Edward Hinz - Pelplin).

3. Muzyka w katedrach polskich dzisiaj (ks. Zdzisław Bernat - Poznań).

Ten ostatni referat został opracowany na podstawie ankiety rozesłanej przez autora do wszystkich ośrodków katedralnych w Polsce.

Swiadomie zaprogramowana doborem referatów wygłoszonych w ramach seminarium konfrontacja między życiem muzycznym w katedrach polskich w przeszłości i współcześnie uwydatniła niepokojące zjawisko generalnego spadku zainteresowania kultywowaniem muzyki religijnej i liturgicznej w ośrodkach katedralnych, które w gruncie rzeczy powinny być instytucjami wiodącymi i inspirującymi życie muzyczne w diecezji. Niemniej spotyka się sporadycznie takie inicjatywy nawiązujące do chlubnych tradycji i wzorów z przeszłości Kościoła, które wydatnie przyczyniają się do kultywowania muzyki religijnej i liturgicznej na dobrym profesjonalnym poziomie zarówno pod względem wykonawczym, jak też pod względem doboru repertuaru. Nadzieję budzi fakt wzrostu zainteresowania muzyka chóralną w wielu ośrodkach katedralnych. Niektóre chóry katedralne nie tylko współuczestniczą w tworzeniu oprawy muzycznej nabożeństw liturgicznych, ale coraz częściej biorą udział w wykonywaniu nawet cyklicznych koncertów muzyki religijnej. Natomiast niepokój może budzić fakt stosunkowo małego zainteresowania muzyków katedralnych chorałem gregoriańskim, wykonywanym aktualnie w większości kościołów katedralnych w zasadzie sporadycznie.

Ze statystycznego punktu widzenia korzystnie przedstawia się poziom wyksztaicenia zawodowego organistów i dyrygentów w ankietowanych kościołach katedralnych. Większość z nich legitymuje się dyplomem ukończenia wyższych studiów muzycznych. Zatem jedynie słabym ich rozeznaniem w skarbcu tradycyjnej muzyki kościelnej można tłumaczyć fakt żenująco małego zainteresowania muzyków kościelnych repertuarem muzyki dawnej, kosztem preferowania muzyki xiX-wiecznej i późniejszej, nie zawsze w peini korespondującej zarówno pod względem treściowym, jak i artystycznyin z powaga nabożeństwa liturgicznego.

Niezbyt dobrze przedstawia się też stan instrumentów muzycznych funkcjonujących w kościołach katedralnych. Jako swoiste curiosum można traktować przypadek przeprowadzenia ostatniego remontu organów ka- 
tedralnych w roku... 1948 (sic!). O tym jednak, że nie jost to praktyka odosobniona może świadczyć fakt, iż $w$ innym ośrodku katedralnym instrument był remontowany ostatnio... 26 lat temu! W tym kontekście optymizmem może napawać jedynie fakt, że po II wojnie światowej zbudowano w ankietowanych katedrach polskich 10 nowych instrumentów; więlrszość z nich stanowią organy nie ustępujące swoimi możliwościami brzmieniowymi i walorami technicznymi renomowanym instrumentom zagranicznym.

W dyskusjach zaakcentowano ponadto, iż obserwowane powszechnie zubożenie oprawy muzycznej nabożenstw liturgicznych nie zostało spowodowane - jak się powszechnie mniema w niektórych kręgach - reformą liturgiczną, lecz jest przede wszystkim wynikiem niewłaściwej i niejednokrotnie niekompetentrej interpretacji dyrektyw liturgicznych oraz wskazan Vaticanum II. Związane z tym często na zasadzie skutku osłabienie ducha wiary wykonawców sprzyja traktowaniu muzyki religijnej, a nawet liturgicznej, jako środka đo realizacji własnych ambicji arłystycznych, usuwając na daleki plan uśvięcanie wiernych i chwałę Bożą. Niejednokrotnie zapomina się o tym, że głównym zadaniem muzyki religijnej, a szczególnie liturgicznej, podobnie zresztą jak i całej sztuki sakralnej, jest takie kształtowanie zmysłu estetycznego człowieka, aby czlowiek, jako ubogacona wewnętrznie przeżyciami estetycznymi osobowość zdolna do uaktywniania sfery ducha, mógł doskonalej wielbić Boga i wydatniej pomnażać bezinteresownie Jego chwałę w świecie.

\title{
REFLEKSJE MATERIALY DUSZPASTERSKIE
}

\author{
O. Ludwik Mycielski OSB
}

\section{PRZYPOWIESC O POIEDNANIU \\ BIBLIJNE WPROWADZENIE DO ADHORTACJI APOSTOLSKEJ JANA PAWLA II "RECONCILIATIO ET PAENITENTIA"}

Trzon Ewangelii według św. Eukasza stanowi opis podróży Jezusa do Jerozolimy. Zaczyna się on stwierdzeniem:

„Gdy dopełnił się czas Jego wzięcia - postanowił nieodwołalnie iść do Jerozolimy"; dosłownie: tò prósōpon estérisen — ukierunkował, „uczynił twardym” swe oblicze, aby wstępować ku Kalwarii - ku temu miejscu, gdzie dokona dzieła zbawienia, ofiarowania grzesznym ludziom łaski powrotu do Ojca. 